\title{
哺乳類螖牛の外有毛細胞における膜輸送
}

\author{
金子 敏彦
}

（耳鼻咽喉科学講座）

\section{Membrane Traffic in Outer Hair Cells of the Adult Mammalian Cochlea}

\author{
Toshihiko KANEKO
}

(Department of Otolaryngology)

\begin{abstract}
はじめに
蝸牛の感覚細胞として 2 種類の有毛細胞, 内有 毛細胞と外有毛細胞が存在する. 音信号は内有毛 細胞より求心性纎維を通じて経由して伝えられ る. 外有毛細胞は能動的運動能を持ち音信号を増 幅するとされている (Dallos \& Harris, 1978). 外有 毛細胞は少なくとも $70 \mathrm{kHz}$ までの周波数に反応し て機械的な力を発生する (Frank et al., 1999). その 能動的運動は外有毛細胞側壁に高密度（少なくと も 7,500/ $\mu \mathrm{m}^{2}$, Huang \& Santos-Sacchi, 1993）に存 在するプレスチンによっておこる (Zheng et al., 2000). しかし, 外有毛細胞のプレスチンの代謝は ほとんど解明されていない.

近年, 蛍光色素 FM1-43 を用いて endocytosis の 機能を検討した論文が多く見られる，FM1-43 は 可逆的に脂質二重層に結合し，細胞膜に結合して いる間にendocytosisによって取り込まれることに より，小胞の可視化を可能とする.内取の有毛細 胞頂部における endocytosis は非常に早く, rapid endocytosis と呼ばれ注目を集めている（Meyer et al., 2001; Griesinger et al., 2002, 2004). Rapid endocytosis は内分泌細胞で有名な現象であり, 細 胞内 $\mathrm{Ca}^{2+} /$ Calmodulin によって制御されていると 考えられている. 今回の報告においては, rapid endocytosisによって取り込まれた細胞膜の運搬 先, そして, 細胞内 $\mathrm{Ca}^{2+} /$ Calmodulin の影響を検 討した。
\end{abstract}

\section{方法 \\ 外有毛細胞の単離}

200-400 g の有色モルモットから外有毛細胞を 単離した。側頭骨を取り出し泠却したハンクス氏 液 $\left(4^{\circ} \mathrm{C}\right)$ に保存し, 実験を行う直前に側頭骨よ り外有毛細胞を単離した. poly-L-lysine によって コーティーングされた coverslip 上の $1.0 \mathrm{ml}$ ハンク ス氏液内に外有毛細胞を含むコルチ器を置き, 100- $\mu \mathrm{L}$ のマイクロピペットを用いて機械的に単 離、その後 coverslip に定着するように 10 分間放 置した後, 実験を行った. なお, 外有毛細胞は健 康な状態に見える細胞のみを使用した。 また，す べての実験は $21.5 \pm 0.5^{\circ} \mathrm{C}$ の室温に調節された環 境で行われた.

\section{虽光色素}

endocytosis や transcytosis を調べるため, 蛍光色 素 FM1-43 (Molecular Probes, Leiden, the Netherlands）を用いた. dimethiylsulphoxide を用いて作 られた $20 \mathrm{mM}$ のストック溶液を $-20^{\circ} \mathrm{C}$ で保存し た. 実験直前にハンクス氏液にて $20 \mu \mathrm{M}$ の最終 濃度に調節した，FM1-43 は borosilicate glass capillary (GC150F-10, Harvard Apparatus, Edenbridge, UK）に満たし， pressure application にて細胞に局 所投与した (Transjector 5246, Eppendorf). キャピ ラリーの先端は $2.5 \mu \mathrm{m}$ に調節し (DMZ Universal Puller, Zeitz-Instrumente, Augsburg, Germany). キャピラリー先端はマイクロマニュプレーターに 
て細胞中央部から約 $40 \mu \mathrm{m}$ の位置に合わせた (Mini 25, Luigs and Neumann, Ratingen, Germany). この方法によって局所投与することにより FM143 は細胞全体を包み込む様に投与される. なお, 先端の位置（頂部，中央部，底部）による細胞内 虽光信号への影響はなかった。

\section{薬片付加}

rapid endocytosis は細胞内への $\mathrm{Ca}^{2+}$ 流入がト リガーと考えられている（Neher \& Zucker, 1993; Artalejo et al., 1995; Meyer et al., 2001; Griesinger et al., 2002, 2004). 細胞内 $\mathrm{Ca}^{2+}$ 依存性を調べるた め, 細胞内 $\mathrm{Ca}^{2+}$ キレーターである BAPTA-AM を 用いた. BAPTA-AM $(25 \mu \mathrm{M})$ を 30 分間付加し, ハンクス氏夜にて wash out した後 FM1-43 を局所 投与した. また Calmodulin の影響を調べるため, Calmodulin 依存性リン酸抑制剂である Trifluoperazine (TFP; $20 \mu \mathrm{m}$; Levin \& Weiss, 1978; Cook et al., 1994; Vandonselaar et al., 1994）を 15 分間付加し, wash-out せずに FM1-43 を投与した.

\section{共焦点レーザスキャン顕碳鏡}

蛍光の観察にはZeiss 社の共焦点レーザスキャン 顕微鏡 LSM510を用いた (Oberkochen, Germany). 正立型顥微鏡 Axioskop 2 FS MOT に対物レンズに は Zeiss 40× (IR-achnoplan, water-immersion lens NA0.8, WD $3.61 \mathrm{~mm}$ ）を用いた. FM1-43 の虽光は $480 \mathrm{~nm}$ のアルゴンレーザーにて励起され，505 nm 以上のロングパスフィルターを用いて観察をし た. 観察した画像は 12 ビットで $256 \times 512$ ピクセ ルか $512 \times 512$ ピクセルの解像度で保存した，蛍 光信号の解析には Zeiss LSM510, フォトショップ 6.0 (Adobe), Origin 7 (Origin Lab) を用いた.

\section{結果}

\section{細胞内輸送}

円筒形の外有毛細胞における細胞内輸送を詳 細に検討した. 図 $1 \mathrm{~A}$ に示す細胞内各部位におけ るFM1-43 の蛍光变化を観察した，蛍光の経時变 化を図 1B に示した。 ピペットを用いて FM1-43 を 30 秒間， 300 秒毎に局所投与を 3 回試みた. stereocilia を含む細胞膜の部位では投与直後より 虽光強度は上昇し, FM1-43 投与中止後は速やか に exponentiallyに低下が見られ，ほぼ投与前の強
度になった. infracuticular zone（細胞頂部，細胞 内）においては FM1-43 投与中止後も営光強度の 上界が見られ30秒程で信号強度の exponentially 減少が始まった。 しかし, 虽光強度は次の色素付 加までに initial levelにまでは低下しなかった.

細胞底部（細胞核近傍）における営光強度の変 化は特徵的で、蛍光強度は徐々に上昇し続けた。 細胞底部における蛍光は hot spot 等も見られず均 一である (図 1D).FM1-43 投与後の急激な蛍光 強度上昇も見られないことから，この部位での営 光強度の上昇は外有毛細胞頂部で取り込まれた小 胞が底部に transport されていると考えられる。

\section{細胞内輸送速度}

図 1A，C に示すように外有毛細胞長軸に沿って 細胞内の何ヶ所か調べると, 頂部から底部にいく につれ，萤光強度上昇の開始点の遅延が見られた。 これにより細胞内輸送速度を $0.37 \pm 0.01 \mu \mathrm{m} / \mathrm{s}$. と 計算することが可能であった. 15 の細胞からの平 均では $0.36 \pm 0.03 \mu \mathrm{m} / \mathrm{s}$. であった.

\section{細胞内 $\mathrm{Ca}^{2+} /$ Calmodulin 低存性 rapid endocytosis}

我々は細胞内 $\mathrm{Ca}^{2+}$ キレーターである BAPTAAM と calmodulin 阻害剤 TFP を用いた, 両者とも コントロールの実験に比較して, rapid endocytosis を著明に抑制した（図 2)。この結果により，rapid endocytosis は細胞内 $\mathrm{Ca}^{2+} /$ Calmodulin により制御 されていることが解った.

\section{考 察 \\ rapid endocytosis 之細胞内輸送}

我々は細胞頂部より取り込まれた小胞がヘンゼ ン体, 細胞側壁そして細胞核近傍の細胞底部に輸 送されることを示した. Kachar（1997）は電子顕 微鏡を用いてウシガエルの前庭有毛細胞の頂部を 観察し, 2 種類の小胞; clathrin-coated pits と nonclathrin-coated pits を発見した. rapid endocytosis は clathrin を必要としない現象と考えられており (Artalejo et al., 1995)， 小胞形成必要な時間はわず か 1 秒以下と考えれられている。 一方, clathrindependent endocytosis では小胞形成に数百秒の時 間が必要である（Henkel \& Almers et al., 1996). Griesinger（2004）は外有毛細胞に抢いて, clathrindependent endocytosis $と$ non-clathrin-dependent 
A

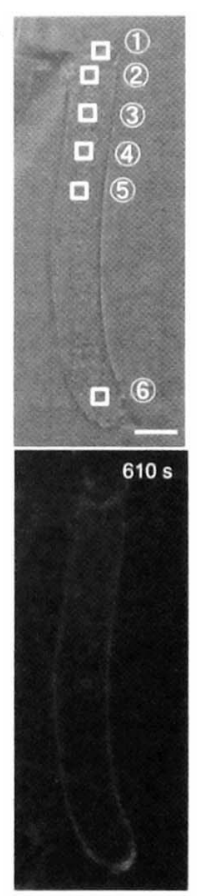

B 50

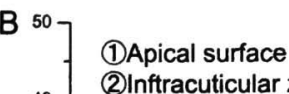

(2) Inftracuticular zone

(6) Base

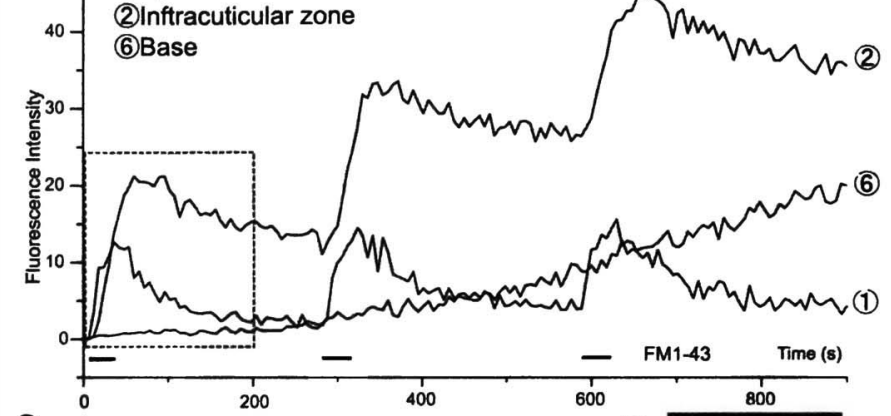

C
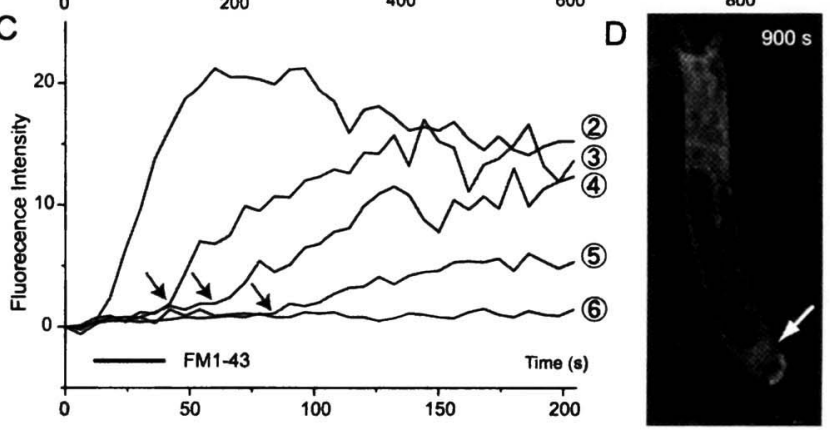

困 1 FM1-43 付加による蛍光の経時变化.（A）上図：蛍光を付加した細胞. 下図：610 秒における営光变化. 細胞全 体と内部に蛍光が見られる。 スケールバーは $10 \mu \mathrm{m}$. (B) FM1-43は 30 秒間, 300 秒ごとに付加した. stereocilia を含む細胞膜の部位では投与直後より蛍光強度は上昇し. FM1-43 投与中止後は速やかに exponentially に低下が 見られ、ほほ投与前の強度になった（1)． infracuticular zone（細胞頂部。細胞内）においては FM1-43 投与中 止後も蛍光強度の上昇が見られ 30 秒程で信号強度の exponentially な減少が始まった. しかし. 蛍光強度は次の 色素付加までに initial level にまでは低下しなかった (2)），細胞底部（細胞核近傍）における蛍光強度の変化は 特徵的で, 蛍光強度は徐々に上昇し続けた (6). (C) ヘンゼン体 (頂部) から細胞核（底部）になるにつれて, 虽光上昇開始点の遅延が見られる (2) (6)). 細胞内の小胞の移動速度が計算可能となる $(0.37 \pm 0.01 \mu \mathrm{m} / \mathrm{s}$.).こ の図は（B）の点線の部分を拡大している.（D） 900 秒の時点の蛍光变化. 細胞核近傍（底部）に色素の集積が 見られる (矢印).

endocytosis の両方が存在する事を示した，我々は clathrin-dependent endocytosis については検討し ていないが、今回の実験では細胞内の蛍光観察に 1 秒以下の時間しか必要としておらず, 我々が観 察した endocytosis は clathrin-independent である rapid endycotisis と考えられる.

我々が今回観察した細胞内運搬速度 $0.36 \pm 0.03$ mm/s.（n15）は微小管に沿った細胞内運搬の過去 の報告に一致する (Nakata et al., 1998; Toomre et al., 1999; Kipp \& Arias, 2002; Mundy et al., 2002). 微 小管は一般的に細胞内小胞の運搬に重要な役割を 果たしていると考えれられている (Kachar et al., 1997). 外有毛細胞でも微小管は細胞全体に見ら れ特に細胞頂部，細胞底部により多く存在するこ とが確認されている（Furness et al., 1990）。 以上
より我々の観察した細胞内小胞の移動は微小管に 沿った現象と考えられる.

\section{$\mathrm{Ca}{ }^{2+} /$ Calmodulin の影響}

カルシウムの細胞内流入は rapid endocytosis の トリガーと考えられている (Neher \& Zucker, 1993; Artalejo et al., 1995; Meyer et al., 2001; Griesinger et $a l ., 2002,2004)$. 細胞内 $\mathrm{Ca}^{2+}$ キレーターBAPTA$\mathrm{AM}$ を用いた実験では, 細胞内 $\mathrm{Ca}^{2+}$ 濃度低下では rapid endocytosis の活動性が低下する事を確認し た. rapid endocytosis では calmodulin $は \mathrm{Ca}^{2+} レ セ$ プターとして働く可能性の有ることが示唆されて いる (Artalejo et al., 1996). 我々は今回 calmodulin inhibitor である TFP を用いて rapid endocytosis の 抑制を確認した。 

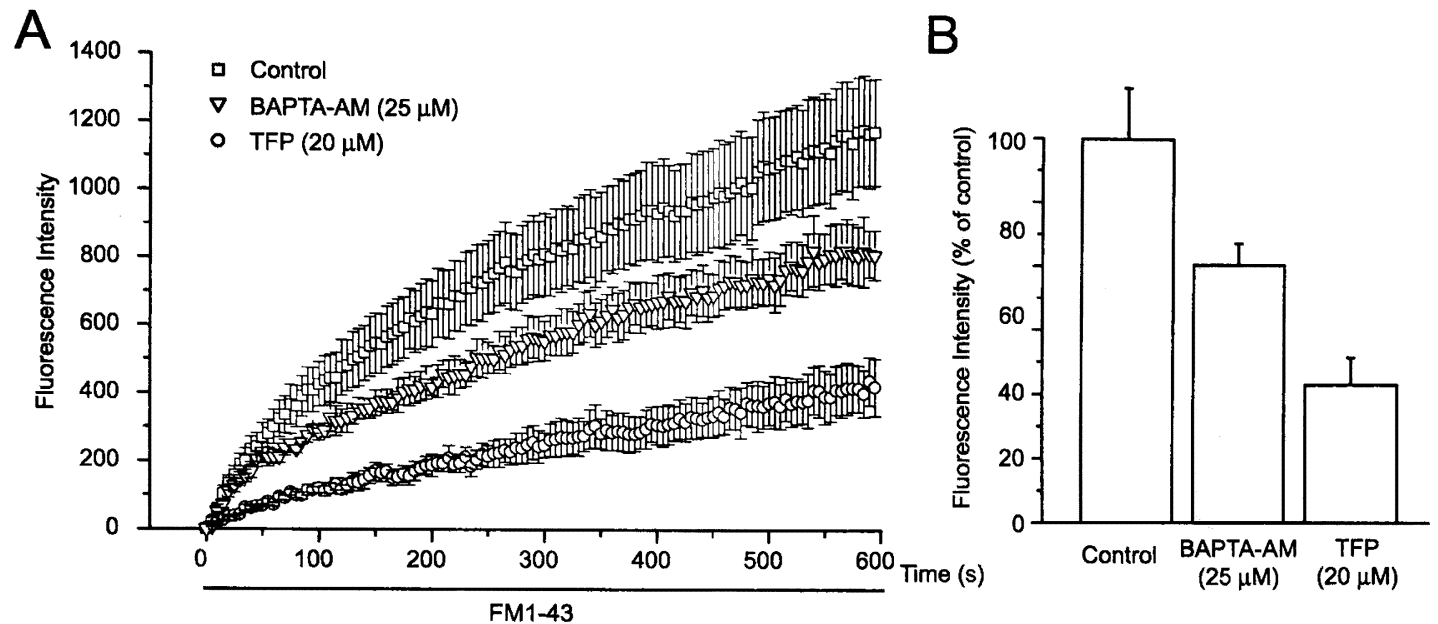

図 2 細胞内 $\mathrm{Ca}^{2+}$ キレーターと Calmodulin 阻害剤による蛍光上昇の抑制. 細胞内 $\mathrm{Ca}^{2+}$ は BAPTA-AM $(25 \mu \mathrm{m})$ によっ てキレートされた. Calmodulin は Trifluoperazine (TFP, $20 \mu \mathrm{m})$ によって阻害されている. 蛍光変化はへンゼン 体の領域で計測した（A）虽光の経時変化（Control n6; BAPTA-AM n4; TFP n4).（B）600 秒の地点における蛍 光変化. 両薬剤共に虽光強度の抑制が見られる。

\section{rapid endocytosis の役割}

これまでtranscytosisによって運搬される様々な 物質が同定されている（Tuma \& Hubbard, 2003）. 細胞膜タンパク質は一定の寿命を持っており，そ れゆえ持続的に交換される必要がある. Endocytosis, exocytosis は細胞膜タンパク質代謝に関 わるメカニズムであることが知られている，過去 の報告では細胞側壁に存在するプレスチンは非常 に高密度であり（Huang \& Santos-Sacchi, 1993）, 活発なタンパク質代謝が必要と考えられている (Meyer et al., 2001; Griesinger et al., 2004). rapid endocytosis はこのプレスチンのリサイクリング に関わっているかもしれないと考察されている. 実際，今回の報告において endocytosis によって取 り込まれた細胞膜は，細胞頂部からタンパク質代 謝に関わる ER やゴルジ体の集合体であるへンゼ ン体（Saito, 1983）への運搬される事を確認して いる.

rapid endocytosis の役割として我々は神経伝達 物質の運搬という可能性も考えている，神経伝達 物質のグルタミン酸塩とアスパラギン酸塩は有毛 細胞に存在するだけでなく，周辺の細胞にも存在 する (Altschuler et al., 1989; Usami \& Ottersen, 1996).また有毛細胞の支持細胞であるダイテルス 細胞には glutamate-aspartate transportor (GLAST)
の存在が確認されている (Furness et al., 2002)。ま た,グルタミン酸塩とアスパラギン酸塩の濃度は perilymph に比して endolymph に非常に高いこと が示されている (Thalmann et al., 1981)。グルタミ ン酸塩やアスパラギン酸塩は神経伝達物質とし てだけでなく，細胞運動のエネルギー源としても 重要と考えられている（Erecinska \& Silver, 1990; Usami \& Ottersen, 1996; Ottersen et al., 1998). も しかするとグルタミン酸塩とアスパラギン酸塩 は，外有毛細胞においては高周波数に伴う運動能 のエネルギー源として，内有毛細胞においては， その運動能にを反映した神経伝達物質として必要 ではないかと考察する.

いずれにせよ，今回報告した細胞内輸送によっ て運搬される物質を同定することが次の大きな目 標である。

\section{文献}

1) Altschuler, R. A., Sheridan, C. E., Horn, J.W. and Wenthold, R. J.: Immunocytochemical localization of glutamate immunoreactivity in the guinea pig cochlea. Hear Res, 42: 167-173, 1989.

2) Artalejo, C. R., Elhamdani, A. and Palfrey, H.C.: Calmodulin is the divalent cation receptor for rapid endocytosis, but not exocytosis, in adrenal chromaffin cells. Neuron, 16: 195-205, 1996. 
3) Artalejo, C. R., Henley, J. R., McNiven, M. A. and Palfrey, H. C.: Rapid endocytosis coupled to exocytosis in adrenal chromaffin cells involves $\mathrm{Ca}^{2+}, \mathrm{GTP}$, and dynamin but not clathrin. Proc Natl Acad Sci USA, 92: 8328-8332, 1995.

4) Cook, W. J., Walter, L. J. and Walter, M. R.: Drug binding by calmodulin: crystal structure of a calmodulintrifluoperazine complex. Biochemistry, 33: 15259 15265, 1994.

5) Dallos, P. and Harris, D.: Properties of auditory nerve responses in absence of outer hair cells. J Neurophysiol, 41: 365-383, 1978.

6) Erecinska, M. and Silver, I. A.: Metabolism and role of glutamate in mammalian brain. Prog Neurobiol, 35: 245-296, 1990.

7) Frank, G., Hemmert, W. and Gummer, A. W.: Limiting dynamics of high-frequency electromechanical transduction of outer hair cells. Proc Natl Acad Sci USA, 96: 4420-4425, 1999.

8) Furness, D. N., Hackney, C. M. and Steyger, P. S.: Organization of microtubules in cochlear hair cells. J Electron Microsc Techn, 15: 261-279, 1990.

9) Furness, D. N., Hulme, J.A., Lawton, D. M. and Hackney, C. M.: Distribution of the glutamate/aspartate transporter GLAST in relation to the afferent synapses of outer hair cells in the guinea pig cochlea. J Assoc Res Otolaryngol, 3: 234-247, 2002.

10) Griesinger, C. B., Richards, C. D. and Ashmore, J. F: FM1-43 reveals membrane recycling in adult inner hair cells of the mammalian cochlea. J Neurosci, 22: 3939-3952, 2002.

11) Griesinger, C. B., Richards, C. D. and Ashmore, J. F.: Apical endocytosis in outer hair cells of the mammalian cochlea. Eur J Neurosci, 20: 41-50, 2004.

12) Henkel, A. W. and Almers, W.: Fast steps in exocytosis and endocytosis studied by capacitance measurements in endocrine cells. Curr Opin Neurobiol, 6: 350-357, 1996.

13) Huang, G. and Santos-Sacchi, J.: Mapping the distribution of the outer hair cell motility voltage sensor by electrical amputation. Biophys J, 65: 2228-2236, 1993.

14) Kachar, B., Battaglia, A. and Fex, J.: Compartmentalized vesicular traffic around the hair cell cuticular plate. Hear Res, 107: 102-112, 1997.

15) Kipp, H. and Arias, I. M.: Trafficking of canalicular $\mathrm{ABC}$ transporters in hepatocytes. Annu Rev Physiol, 64: 595-608, 2002.

16) Levin, R. M. and Weiss, B.: Specificity of the binding of trifluoperazine to the calcium-dependent activator of phosphodiesterase and to a series of other calciumbinding proteins. Biochim Biophys Acta, 540: 197-204, 1978.

17) Meyer, J., Mack, A. F. and Gummer, A. W.: Pronounced infracuticular endocytosis in mammalian outer hair cells. Hear Res, 161: 10-22, 2001.

18) Mundy, D. I., Machleidt, T., Ying, Y. S., Anderson, R. G. and Bloom, G. S.: Dual control of caveolar membrane traffic by microtubules and the actin cytoskeleton. $\mathrm{J}$ Cell Sci, 115: 4327-4339, 2002.

19) Nakata, T., Terada, S. and Hirokawa, N.: Visualization of the dynamics of synaptic vesicle and plasma membrane proteins in living axons. J Cell Biol, 140: 659674, 1998.

20) Neher, E. and Zucker, R. S.: Multiple calcium-dependent processes related to secretion in bovine chromaffin cells. Neuron, 10: 21-30, 1993.

21) Ottersen, O. P., Takumi, Y., Matsubara, A., Landsend, A. S., Laake, J. H. and Usami, S.: Molecular organization of a type of peripheral glutamate synapse: the afferent synapses of hair cells in the inner ear. Prog Neurobiol, 54: 127-148, 1998.

22) Saito, K.: Fine structure of the sensory epithelium of guinea-pig organ of Corti: subsurface cisternae and lamellar bodies in the outer hair cells. Cell Tissue Res, 229: 467-481, 1983.

23) Thalmann, R., Comegys, T. H., DeMott, J. E. and Thalmann, I.: Steep gradients of amino acids between cochlear endolymph and perilymph. Laryngoscope, 91: 1785-1791, 1981.

24) Toomre, D., Keller, P., White, J., Olivo, J. C. and Simons, K.: Dual-color visualization of trans-Golgi network to plasma membrane traffic along microtubules in living cells. J Cell Sci, 112: 21-33, 1999.

25) Tuma, P. L. and Hubbard, A. L.: Transcytosis: crossing cellular barriers. Physiol Rev, 83: 871-932, 2003.

26) Usami, S. and Ottersen, O. P.: Aspartate is enriched in sensory cells and subpopulations of non-neuronal cells in the guinea pig inner ear: a quantitative immunoelectron microscopic analysis. Brain Res, 742: 43-49, 1996.

27) Vandonselaar, M., Hickie, R.A., Quail, J. W. and Delbaere, L. T.: Trifluoperazine-induced conformational change in $\mathrm{Ca}^{2+}$-calmodulin. Nat Struct Biol, 1: 795801, 1994.

28) Zheng, J., Shen, W., He, D. Z., Long, K. B., Madison, L. D. and Dallos, P.: Prestin is the motor protein of cochlear outer hair cells. Nature, 405: 149-155, 2000. 